\title{
AN ANALYSIS STUDENTS' WRITING OF USING GENERIC STRUCTURE OF HORTATORY EXPOSITION TEXT BY THE SECOND GRADE STUDENTS OF MAN 2 KEDIRI ACADEMIC YEAR 2019/2020
}

\author{
Ayu Novitasari, Kristanti Yuntoro Putri
}

\begin{abstract}
This research aimed 1) to know the generic structure written in the hortatory exposition text. 2) to know the quality of generic structure written in the hortatory exposition text, and 3) to know the problems are faced in using the generic structure of written hortatory exposition text. This research used the descriptive qualitative method and used students' writing of Hortatory Exposition text to be analyzed. This research sample was 25 from 32 students of second-grade at MAN 2 Kediri, from XI-MIPA 3. Data collection was carried out by conducting writing test and interview. The data was analyzed by using contextual data which includes three procedures such as: reduction, data presentation, and drawing conclusions and verification. Furthermore, the researcher only used an external auditor to review the entire project's data validity. This result showed that there were five problems that are faced by students 1) developing the ideas into a paragraph, 2) translating the text into English, 3) determining the topic or title in accordance with the theme, 4) making recommendations, 5) making thesis and argumentation. The researcher suggested that the teacher should explain the materials step by step and intensively.
\end{abstract}

Keyword: generic structure, hortatory exposition text, writing

\section{INTRODUCTION}

There are four language skills that have to be mastered by students there are listening, speaking, reading, and writing. Writing can be one of the ways how to express student's idea, opinion, and their information to other people in a text form. In a way, how the students express their idea, opinion, and information, they need to formulate what they are going to write in a good sentence and paragraph. Moreover, Syahrin et al. (2019) stated that writing is a process of thinking to create the idea, thinking about how to express their thought into good writing into good writing and arranging the ideas into statements and paragraphs clearly.

According to Fauziah \& Sudarmaji (2020), writing is a written product of thinking, drafting, and revising procedures that require specialized skills. It means that writing has complicated steps that should be done by the writer to produce a written text, so it needs a special skill to do it. In writing also, the writer should have knowledge of writing elements and the important basic element to do good writing. Based on Walker (2010), stated that there are five elements of good writing, there are purpose, audience, clarity, unity, and coherence. It means that the writer 
cannot do in any old way to write a text because there are some elements that should be applied to do good writing.

Based on Indonesia 2013 curriculum, there are some text types that should be learned by students of senior high school, such as narrative text, descriptive text, report, exposition text, etc. Exposition text is classified into two kinds; there are analytical exposition and hortatory exposition. Analytical exposition text has to persuade the readers to believe what the writer believes, while hortatory exposition has the purpose of persuading the readers to do or should not be done.

In Indonesia 2013 curriculum, especially for second-grade students of senior high school, the students were expected to be able to identify the social function, generic structure, language features of hortatory exposition text and able to make hortatory exposition text cohesively, but based on the writer observation, the students still confused to express their idea and opinion into the text and confused to determine the generic structure and language features. Because of that, some of the students writing are still having low quality in writing generic structure.

Based on Husein \& Pulungan (2017), the generic structures of hortatory exposition text are thesis, argumentation, and recommendation. In the thesis, there is a statement or announcement of issue concern. In an argument, there are reasons for concern that will lead to a recommendation. In recommendation, there is a statement of what should or should not happen or be done based on the arguments given. All of the three aspects above (Thesis, Argument, and Recommendation) have to be arranged in good order in order to make the reader can understand the content of the hortatory exposition which is presented by the writer.

In the teaching and learning process, difficulties are difficult to avoid for the students. Based on the researcher's observation, the researcher found out that the students in high school are still having many problems, especially in writing. Most students are afraid of making mistakes and making some errors in organizing the generic structure, and many of them are still asking about how to write a hortatory exposition text, especially in writing correct generic structure like thesis, argumentation, and recommendation, although the teacher has explained the material and the students, have known about the theme of hortatory exposition that should they make.

Based on the previous explanation, it can be said that writing a hortatory exposition text is not an easy thing, but it is not an impossible thing to improve. Based on the Program for International Student Assessment (PISA) -the program which put the education system quality in the right order in 72 countries- findings, Indonesia is in the 62 ranks. The rank was obtained by examining the students of 15 years old to know their knowledge in science, reading, and math. From those three subjects, it is believed that they can give participate in social life. In modern society, the competent person cannot only measure by what they know but what they can do and one of the examples in writing.

Writing can be an important lesson because it can train the mindset of students, moreover, the students of high school. High school is the right time to teach students to explore what they have in their minds. One of the ways is teaching them how to write the hortatory exposition because by writing the hortatory exposition, they can practice their critical thinking. Based on Wade \& Tavris (2008: 08), the importance 
of critical thinking is more than supporting daily life that is the most important and fundamental thing for all sciences and knowledge. Because of that, the students must have critical thinking to make them open-minded, have a flexible mind, and easy to understand pint of view from other people.

Therefore, the researcher conducts this research to find out the quality of generic structure written by the student and problems are faced in organizing generic structure. The researcher took MAN 2 Kediri as the research setting of the research. The researcher concludes that, in fact, the students in a writing text are still far from being perfect, even getting difficulty while writing using generic structure. From the explanation above, the researcher is interested in conducting a research entitled "An analysis of students' writing of using the generic structure of hortatory exposition text by the second-grade students of MAN 2 Kediri academic year 2019/2020.

\section{METHOD}

This research used the descriptive qualitative method. It is to find the right way to implement an overall learning process (Sugiyono, 2011). In this research the researcher used students' writing of Hortatory Exposition text to be analyzed. This research sample was 25 from 32 students of second-grade at MAN 2 Kediri, from XI-MIPA 3. Data collection was carried out by conducting writing test and interview. The data is analyzed, contextual data includes three procedures such as: reduction, data presentation, and drawing conclusions and verification. Furthermore, this research, the researcher only used an external auditor to review the entire project's data validity.

\section{RESEARCH FINDING}

Analysis of Generic Structure in Students' Hortatory Exposition Text.

The table below is the recapitulation of the use of generic structure in students' hortatory exposition text consists of the thesis statement, argumentation, and also recommendation. 
Table 4.1 The Recapitulation Of Generic Structure

\begin{tabular}{|c|c|c|c|c|}
\hline \multirow{2}{*}{ Respondent } & \multicolumn{3}{|c|}{ Generic Structure } & \multirow{2}{*}{ Tota } \\
\hline & Thesis & Argumentation & Recommendation & \\
\hline R1 & $\checkmark$ & $\checkmark$ & $\checkmark$ & 3 \\
\hline $\mathbf{R 2}$ & $\checkmark$ & $\checkmark$ & $\checkmark$ & 3 \\
\hline $\mathbf{R 3}$ & $\checkmark$ & $\checkmark$ & $\checkmark$ & 3 \\
\hline R4 & $\checkmark$ & $\checkmark$ & $\checkmark$ & 3 \\
\hline R5 & $\checkmark$ & $\checkmark$ & $\checkmark$ & 3 \\
\hline R6 & $\checkmark$ & - & - & 1 \\
\hline $\mathbf{R 7}$ & $\checkmark$ & $\checkmark$ & $\checkmark$ & 3 \\
\hline $\mathbf{R 8}$ & $\checkmark$ & $\checkmark$ & $\checkmark$ & 3 \\
\hline R9 & $\checkmark$ & $\checkmark$ & $\checkmark$ & 3 \\
\hline R10 & $\checkmark$ & $\checkmark$ & $\checkmark$ & 3 \\
\hline R11 & $\checkmark$ & $\checkmark$ & $\checkmark$ & 3 \\
\hline R12 & $\checkmark$ & $\checkmark$ & $\checkmark$ & 3 \\
\hline R13 & $\checkmark$ & $\checkmark$ & $\checkmark$ & 3 \\
\hline R14 & $\checkmark$ & $\checkmark$ & $\checkmark$ & 3 \\
\hline R15 & $\checkmark$ & $\checkmark$ & $\checkmark$ & 3 \\
\hline R16 & $\checkmark$ & $\checkmark$ & $\checkmark$ & 3 \\
\hline R17 & $\checkmark$ & $\checkmark$ & $\checkmark$ & 3 \\
\hline R18 & $\checkmark$ & $\checkmark$ & $\checkmark$ & 3 \\
\hline R19 & $\checkmark$ & $\checkmark$ & $\checkmark$ & 3 \\
\hline R20 & $\checkmark$ & $\checkmark$ & $\checkmark$ & 3 \\
\hline R21 & $\checkmark$ & $\checkmark$ & $\checkmark$ & 3 \\
\hline R22 & $\checkmark$ & $\checkmark$ & $\checkmark$ & 3 \\
\hline R23 & $\checkmark$ & $\checkmark$ & $\checkmark$ & 3 \\
\hline R24 & $\checkmark$ & $\checkmark$ & $\checkmark$ & 3 \\
\hline R25 & $\checkmark$ & $\checkmark$ & $\checkmark$ & 3 \\
\hline Total & 25 & 24 & 24 & \\
\hline
\end{tabular}

From table 4.1 above about the use of generic structure in students' hortatory exposition text, it can be said that almost all students are able to use the generic structure in writing hortatory exposition text. There are 24 students able to write three stages of generic structure. One student was only able to write 1 stage of generic structure. Hortatory exposition text sample 1 from respondent 4 : 


\begin{tabular}{|c|c|}
\hline \multicolumn{2}{|c|}{ "Vape Hazard" } \\
\hline \begin{tabular}{c} 
Vape is an electric cigarette that is \\
richer than ordinary cigarettes or \\
cigarette form tobacco. So it's not right \\
if you choose to vape as a substitute for \\
tobacco cigarette or regular cigarettes. \\
Some reasons why vape is more \\
dangerous than the ordinary cigarette of \\
tobacco cigarettes are as follows. \\
\hline First, vape contains nicotine, which \\
enters the lung directly. Vape can also \\
explode if there is a leak in battery. \\
Secondly, Amir once smoked a vape \\
in 2017 and leak occurred in his battery \\
so that the vape exploded and caused \\
Amir's mouth break. In the US about \\
$70 \%$ of 25 years old adult die from vape
\end{tabular} \\
\hline $\begin{array}{c}\text { Therefore, if vape is more } \\
\text { dangerous than the ordinary cigarette, }\end{array}$ \\
it is better to use a cigarette or not at \\
all."
\end{tabular}

From the example above it can be seen that the student was able to write 3 stages of generic structure in writing hortatory exposition text.

\section{Analysis of the Quality of Generic Structure in Students' Hortatory Exposition Text}

The table below illustrates the recapitulation of the quality of generic Structure in students' hortatory exposition text. It consists of a thesis statement, argumentation, and also a recommendation. 
Table 4.2 The Recapitulation Quality Of The Generic Structure

\begin{tabular}{|c|c|c|c|c|c|c|c|c|c|}
\hline \multirow{2}{*}{ Respondent } & \multicolumn{3}{|c|}{ Thesis } & \multicolumn{3}{|c|}{ Argumentation } & \multicolumn{3}{|c|}{ Recommendation } \\
\hline & $\mathbf{P}$ & $\mathbf{G}$ & VG & $\mathbf{P}$ & $\mathbf{G}$ & VG & $\mathbf{P}$ & $\mathbf{G}$ & VG \\
\hline R1 & & & $\sqrt{ }$ & $\sqrt{ }$ & & & & & $\sqrt{ }$ \\
\hline $\mathbf{R 2}$ & & & $\sqrt{ }$ & $\sqrt{ }$ & & & & & $\sqrt{ }$ \\
\hline $\mathbf{R 3}$ & $\sqrt{ }$ & & & & & $\sqrt{ }$ & & & $\sqrt{ }$ \\
\hline $\mathbf{R 4}$ & & & $\sqrt{ }$ & & & $\sqrt{ }$ & & & $\sqrt{ }$ \\
\hline R5 & & & $\sqrt{ }$ & & $\sqrt{ }$ & & & & $\sqrt{ }$ \\
\hline R6 & $\sqrt{ }$ & & & & & & & & \\
\hline R7 & $\sqrt{ }$ & & & $\sqrt{ }$ & & & & $\sqrt{ }$ & \\
\hline $\mathbf{R 8}$ & & & $\sqrt{ }$ & & & $\sqrt{ }$ & & & $\sqrt{ }$ \\
\hline R9 & $\sqrt{ }$ & & & & $\sqrt{ }$ & & & & $\sqrt{ }$ \\
\hline R10 & & & $\sqrt{ }$ & & & $\sqrt{ }$ & & & $\sqrt{ }$ \\
\hline R11 & & & $\sqrt{ }$ & $\sqrt{ }$ & & & & & $\sqrt{ }$ \\
\hline R12 & & & $\sqrt{ }$ & $\sqrt{ }$ & & & & $\sqrt{ }$ & \\
\hline R13 & & & $\sqrt{ }$ & & & $\sqrt{ }$ & & & $\sqrt{ }$ \\
\hline R14 & $\sqrt{ }$ & & & $\sqrt{ }$ & & & & $\sqrt{ }$ & \\
\hline $\mathbf{R} 15$ & $\sqrt{ }$ & & & & $\sqrt{ }$ & & & & $\sqrt{ }$ \\
\hline R16 & & & $\sqrt{ }$ & $\sqrt{ }$ & & & & & $\sqrt{ }$ \\
\hline R17 & & $\sqrt{ }$ & & & & $\sqrt{ }$ & & & $\sqrt{ }$ \\
\hline R18 & & & $\sqrt{ }$ & & & $\sqrt{ }$ & & & $\sqrt{ }$ \\
\hline R19 & & $\sqrt{ }$ & & $\sqrt{ }$ & & & $\sqrt{ }$ & & \\
\hline R20 & & & $\sqrt{ }$ & & & $\sqrt{ }$ & & & $\sqrt{ }$ \\
\hline $\mathbf{R 2 1}$ & & $\sqrt{ }$ & & & & $\sqrt{ }$ & & & $\sqrt{ }$ \\
\hline R22 & & & $\sqrt{ }$ & & & $\sqrt{ }$ & & & $\sqrt{ }$ \\
\hline $\mathbf{R 2 3}$ & & $\sqrt{ }$ & & & & $\sqrt{ }$ & & & $\sqrt{ }$ \\
\hline R24 & $\sqrt{ }$ & & & & & $\sqrt{ }$ & & $\sqrt{ }$ & \\
\hline $\mathbf{R} 25$ & & & $\sqrt{ }$ & $\sqrt{ }$ & & & $\sqrt{ }$ & & \\
\hline \multirow{2}{*}{ Total } & 7 & 4 & 14 & 9 & 3 & 12 & 2 & 4 & 18 \\
\hline & \multicolumn{3}{|c|}{ Thesis } & \multicolumn{3}{|c|}{ Argumentation } & \multicolumn{3}{|c|}{ Recommendation } \\
\hline
\end{tabular}

Notes: $P=$ Poor,$G=$ Good, $V G=$ Very Good

From table 4.2 above, it can be concluded that after the researcher analyzed the thesis quality of twenty-five students, the researcher found that there are fourteen students have a very good thesis statement, four students have a good thesis statement, and there are seven students have a poor thesis statement. And for argumentation, it was found there are twelve students have a very good argumentation, and three students have a good argumentation, nine students have a poor argumentation, and the last is for the recommendation it was found there are eighteen students have a very good argumentation, four students have a good argumentation, and two students have a poor argumentation. Hortatory exposition text sample 1 from respondent 13: 


\begin{tabular}{|l|l|}
\hline \multicolumn{2}{|c|}{ "Cigarettes Kill You" } \\
\hline $\begin{array}{c}\text { Smoking can cause smoke that has many } \\
\text { negative impacts, because just one cigarette can }\end{array}$ & \\
take away lives in a minute. In cigarettes there are & Thesis \\
compositions, one of which is carbon monoxide & \\
which is a deadly poisonous gas. & \\
\hline The first, based on data from the ministry of & \\
health there are about 18 million more people who & \\
died from smoking, the cause begins with shortness & \\
of breath, and result in stroke. \\
The second, smoking also causes cancer, \\
among which oral cancer, throat cancer, and other \\
very dangerous cancers. Even though there are \\
already pictures and prohibitions in the cigarette \\
holder. The pictures are explained the disease \\
when consuming it continuously will cause the \\
disease, and the writing prohibits smoking to kill \\
you. However, the reality of the Indonesian people \\
only ignore the picture of the text \\
\hline $\begin{array}{l}\text { Therefore, before you try to smoke think first. } \\
\text { How dangerous cigarettes are to be consumed }\end{array}$ \\
every day, so I strongly do not recommend you or \\
even forbid you to smoke. Then stay away from \\
cigarettes, better to keep than cure.
\end{tabular}

From sample 1 above, the researcher explains that the thesis of this text is classified as a very good thesis because it has clear enough to explain the topic of the text and relate to the topic itself, and the argumentation is classified as very good argumentation because the argumentation explains about the thesis by giving supporting paragraph in this argumentation the writer explain the topic and the last is about the recommendation the researcher classified as very good because it mentions the recommendation clear and relates to the topic.

\section{Problems}

The problems are faced in using the generic structure of written hortatory exposition text will be discussed in this part, after the researcher conducting a written test of hortatory exposition text, the writer interviews the students about their problems in writing text. So here will be shown some categories of what the students' problems are.

\section{Develop the idea to be a paragraph}

The researcher found that there are twelve students who are having difficulties in developing the ideas into a paragraph, and the example interview is presented below. 
"My difficulty in writing hortatory exposition text is when I have to decide the issues or problems which relate to the topic and develop the ideas into a paragraph". (Respondent 1, translated)

\section{Translating the text into English}

After the researcher analyzed the interview with the students, the researcher found there are four students who are having difficulty in translating text to English, and the example interview is presented below.

"My difficulty in writing hortatory text arranges the word into a correct sentence and translate it to English." (Respondent 2, translated)

\section{Determine the title in accordance with the theme.}

When the researcher analyzed the interview with the students, the researcher found seven students are still confused in determining the title/issues that accordance with the topic and an example is presented below.

"My difficulties in writing hortatory exposition text are 1) difficult in determining the issue in accordance with the topic. 2) Develop the idea into paragraph". (Respondent 3, translated)

Based on the explanation above, it can be concluded that students are still having some difficulties in writing hortatory exposition text, such as translating the text into English, develop the idea to be a paragraph, making a recommendation, determine the title in accordance with the theme, and making thesis statement and argumentation.

\section{Making a recommendation}

In making a recommendation, the researcher only found one student that having difficulty in making a recommendation, and the interview text is presented below.

"The difficulties that I found in writing hortatory exposition text is in deciding the recommendation; in my opinion, the difficult part is deciding recommendation/making recommendation."(Respondent 4, translated)

\section{Making a Thesis Statement and Argumentation}

When the researcher analyzed the result of the interview, the researcher found the cause that makes students have low quality in writing a thesis statement. It was caused because the students are still having difficulties in developing the idea to be a paragraph, so the students only know about the topic, but they do not really understand how do to do the thesis which has the main idea, indicates the writer position, and has a specific purpose.

The researcher also found the reason the students still have low quality in making the argumentation because they were having difficulties in arranging the ideas. The students did not know how to arrange their text framework to be a solid text. They just have many ideas, but they did not know which ideas are appropriate to their topic and support their thesis statement, and it makes their argumentations are not related to the topic and the thesis statement. And the example is presented below:

"The difficulties in making hortatory exposition are developing into a solid text" and the second is "my difficulties in writing hortatory exposition text is making 
sentences because the hortatory text has generic structure so from the one paragraph to the other paragraph should continuous each other, so it is a little bit difficult for me. Moreover, if we should translate the text into English, because I still low in vocabulary mastery, but if I translate using dictionary or browsing on the internet, I can do it." (Respondent 5, translated).

\section{DISCUSSION}

In this part, the researcher will discuss the research finding. The generic structure written in hortatory exposition text by second-grade students of MAN 2 Kediri and problems is faced in using the generic structure of written hortatory exposition text.

The researcher found that there is one student of twenty-five students did not write complete stages in the generic structure of the hortatory exposition text, in which there are four stages there are thesis statement, argumentation, and recommendation, but the students were only writing the thesis stamen and giving the conclusion. So it can be said that there are $4 \%$ of students did not write a complete stage of generic. That problem is related to Byrne (1988) categorized three problems in writing skills. There are linguistic, cognitive, and content. The first problem is linguistic. This is related to the writer's skill in writing the correct structure, and because of that, the sentences will unite each other. So if the students are having difficulties in uniting the sentences, it will be difficult to unite the generic structure itself.

Based on the scoring guideline was made by the researcher, the researcher found the quality for each stage of the generic structure was written by the students; there are thesis statement, argumentation, and recommendation

The researcher found there are fourteen students (56\%) got a very good score in writing a thesis because it has a thesis statement and the main idea related to the topic and stated clearly, indicates the writer position and has a specific topic; four students (16\%) got a good score in writing thesis because it has a topic statement, indicates the writer position but it does not have a specific topic, seven students $(28 \%)$ got a poor score in writing thesis because it does not have a thesis statement that relates to the topic. It means that almost half of students in XIMIPA 3 of second grade MAN 2 Kediri still having difficulty in writing a thesis statement

The researcher found twelve students (48\%) got a very good score in writing argumentation because every paragraph has a new argumentation with a new topic, has supporting details are related to the topic sentence, and supported by knowledge, one student (4\%) got good score because it does not have enough supporting details and eleven students (48\%) got poor score because it does not have supporting details. Based on the data above, it can be concluded that many students are having difficulties in writing argumentation

The researcher found eighteen students $(78,26 \%)$ got a very good score in writing recommendation because it has a clear statement of recommendation and relates to the topic, three students $(13,04 \%)$ got a good score in writing recommendation because it does not have a clear statement of recommendation and $(8,69 \%)$ students got a poor score in writing recommendation because it does not contain recommendation statement and the recommendation does not relate to the 
topic. It means that almost all students do not have any difficulties in writing a recommendation

The researcher found that there five problems are faced by students in writing hortatory exposition text; the most problems are developing the ideas to be a paragraph which takes ten students $(37,03 \%)$, the second is translating into the English which takes seven students $(25,92 \%)$, the third is determining the title according to the theme which takes seven students $(25,92 \%)$, the fourth is writing recommendation which takes one student $(3,70 \%)$. The last is doing a thesis which takes one student $(3,70 \%)$, and argumentation which takes one student $(3,70 \%)$. From the findings, the researcher concluded that the problems are faced by students were reflected that actually, students are having difficulties in making thesis and argumentation, because their thesis and argumentation are still found many mistakes, but they have not understood and realized it well.

The problem is faced by students in writing also relates to Widearti (2005:22) stated that there are some problems faced by students in writing. The problems are: (1) finding the topic of cases that will be written, (2) finding the material or references, (3) arranging argumentation.

The first problem faced by students in developing the ideas into a paragraph and it is proved by conducting the interview with the students, and it showed that they still have difficulties in developing their ideas into a paragraph. In addition, some of them said they did not have more ideas or words to say about their topic. That problem is related to (Clifford 1987), who stated that learners of English as a second or foreign language also face problems of exploring ideas and thought to communicate with others.

The second problem is translating the text into English because the students are less of vocabulary and did not know how to choose the correct vocabulary in translating the sentences and it makes the students having difficulties in translating the text into English, and it is related to Reid (1983) in Melese (2007:13) when the writer practices the choice of vocabulary that would reflect a concern for the reader and the purpose of writing, the composition was written by the students would become sensitive to his/her reader. However, writing in a second language using the appropriate words in the appropriate place is a problem for students.

The third problem faced by students is determining the topic or title, and it is proved by the students written text that some of their title or topic is not related to their explanation or generic structure and it is related to Widearti (2005:22) stated that difficulties in finding topic or title are cliché problem that is really common found and did by every people who wants to start to write an essay. Everyone will feel that there is no topic or good cases that appropriate to write.

The fourth problem is making a recommendation on which recommendation is the last stage of generic structure in hortatory exposition text, and it is related to Byrne (1988) stated that there are three difficulty problems in writing skill there are linguistic, cognitive, and content. And this is related to writer skill in writing the correct stages, and because of that, the sentences will be united one each other. And the final result is the written text can be understood and enjoyed by the reader.

The fifth problem is making the thesis statement and argumentation, and it is related to Widearti $(2005: 22)$ stated that there are some difficulties in writing 1) 
difficulty in finding topic or cases, 2) difficulty in looking for or finding materials or references, 3) difficulty in arranging the effective sentences, 4) difficulty in arranging a good paragraph. The fourth difficulty is related to students' difficulty in arranging the paragraph in making the thesis statement and argumentation. Similarly to Clifford (1987) suggests that the teachers should encourage students to focus on the message, ideas, or thoughts they wish to convey rather than grammar, spelling, punctuation, and others. Based on the explanation above, it can be said that it is natural if the students are still having difficulties in arranging a thesis statement and argumentation.

From the five texts were analyzed by the external auditor the researcher concluded that the researcher has different scoring in good and very good version, the external auditor classified the two very good thesis statement to the good thesis statement. And also the external auditor classified the five very good recommendation for the good recommendation.

\section{CONCLUSION}

Based on the collecting data and discussion in the previous chapter, the researcher concludes that $96 \%$ of second-grade students in MAN 2 Kediri are able to write the complete stages of generic structure in writing hortatory exposition text, which consists of a thesis statement, argumentation, and recommendation.

The result of this research shows the texts written by students of second-grade students of MAN 2 Kediri are having low quality in using generic structure in writing hortatory exposition text. There are $56 \%$ of thesis statements are classified as very good, good $16 \%$, and poor $28 \%$. There is $48 \%$ argumentation, which is classified as very good, $4 \%$ good, and $48 \%$ poor. There is a $72 \%$ recommendation, which is classified as very good, $12 \%$ is good, and $16 \%$ as poor. From the data collecting and result of the researcher's analysis hortatory exposition text written by students, most of them are having low quality in arranging argumentation which sometimes does not have relation to the thesis statement, and the second is making thesis argument which less clear and the last is the recommendation.

Based on the collecting data and result of researcher's analysis on the interview of problems that are faced by students, it found that the problem is faced by students mostly are developing ideas into paragraph it takes $37,03 \%$, translating the text into English it takes $25,92 \%$, determined the topic accordance with the theme $25,92 \%$, and writing recommendation it takes $3,70 \%$. The last is making thesis 3,70\% and argumentation 3,70. Moreover, making the thesis statement and argumentation only takes $3,70 \%$, but the reality students have low quality in making both stages, it is caused by the students did not understand how to make a good thesis statement and argumentation.

\section{REFERENCES}

Byrne, D. (1988). Teaching Writing Skills. London: Longman Press

Fauziah, F., \& Sudarmaji, I. (2020). The effect of peer-editing technique by using google docs to enhance students' academic writing skills at 1st semester of English department faculty of teacher training and education of Islamic university of Syekh Yusuf. 
Husein, R., \& Pulungan, A. H. (2017). Sumber Belajar Penunjang PLPG 2017 Mata Pelajaran/paket keahlian Bahasa Ing-gris. Jakarta. Kementerian

Kharma, Nayef. (1987). Arab Students' Problems with English Relative Clause.

Syahrin, A., Dawud, D., Suwignyo, H., \& Priyatni, E. T. (2019). Creative Thinking Patterns in Student's Scientific Works. Eurasian Journal of Educational Research, 81, 21-36

Wade, C., Tavris, C. (2008). Psikologi. Edisi Kesembilan. Jilid 1. Jakarta: Erlangga Walker, R. (2010). Five elements of good writing.

Wiedarti, Pangesti. 2005. Menuju Budaya Menulis. Yogyakarta: Tiara Wacana 